\title{
$\nabla$
}

\section{Recurrent cutaneous leishmaniasis}

\author{
Leishmaniose recidiva cútis
}

\author{
Ciro Martins Gomes ${ }^{1}$ \\ Orlando Oliveira de Morais ${ }^{3}$ \\ Raimunda Nonata Ribeiro Sampaio ${ }^{5}$
}

\author{
Fabiana dos Santos Damasco ${ }^{2}$ \\ Carmen Déa Ribeiro de Paula ${ }^{4}$
}

\begin{abstract}
We present a case of an 18-year-old male patient who, after two years of inappropriate treatment for cutaneous leishmaniasis, began to show nodules arising at the edges of the former healing scar. He was immune competent and denied any trauma. The diagnosis of recurrent cutaneous leishmaniasis was made following positive culture of aspirate samples. The patient was treated with N-methylglucamine associated with pentoxifylline for 30 days. Similar cases require special attention mainly because of the challenges imposed by treatment.

Keywords: Leishmaniasis; Leishmaniasis, mucocutaneous; Pentoxifylline; Recurrence; Therapeutics

Resumo: Paciente do sexo masculino, 18 anos. Dois anos após tratamento insuficiente para leishmaniose tegumentar americana, apresentou, na mesma localização, lesão formada por cicatriz atrófica central e nódulos verrucosos na periferia. Era imunocompetente, hígido e negava qualquer trauma local. O diagnóstico de leishmaniose recidiva cutis foi feito através de cultura do aspirado da lesão. Realizou tratamento com N-metilglucamina $(20 \mathrm{mgSbV} / \mathrm{kg} /$ dia) associado à pentoxifilina $(1200 \mathrm{mg} /$ dia) durante 30 dias alcançando cura clínica. Os casos semelhantes requerem atenção diferenciada pela dificuldade ao tratamento.

Palavras-chave: Leishmaniose; Leishmaniose mucocutânea; Pentoxifilina; Recidiva; Terapêutica
\end{abstract}

\section{Report}

We present a case of an 18-year-old male patient from the northeast of Brazil. He had experienced an ulcer on the anterior face of his left thigh which was treated as American Cutaneous Leishmaniasis (ACL). The use of $\mathrm{N}$-methylglucamine $(7 \mathrm{mgSbV} / \mathrm{Kg} /$ day) for 20 days ensured complete healing. However verrucous nodules began to appear at the periphery of the former atrophic scar two years after clinical cure (Figures 1 and 2). The patient presented no immunodeficiency.
A positive $(6 \times 5 \mathrm{~mm})$ Montenegro intradermoreaction was found, in addition to high titer (1:160) of anti-ACL antibodies showed by indirect immunofluorescence. The smear was negative, together with the cultures for mycobacteria and fungus. Histological examination showed pseudoepitheliomatous hyperplasia and linfohistioplasmocitoid granulomas (Figure 3).

\footnotetext{
Received on 25.05.2012.

Approved by the Advisory Board and accepted for publication on 16.10.2012.

Study conducted at Brasilia University Hospital (HUB-UnB) - Brasilia (DF), Brazil.

Conflict of interest: None

Financial funding: None

M.D. Residency Preceptor of Dermatology - Dermatology Department, Brasilia University Hospital (HUB-UnB) - Brasilia (DF), Brazil.

Medical Student - University of Brasilia (UnB) - Brasília (DF), Brazil.

M.D. Dermatologist - Dermatology Department, Brasilia University Hospital (HUB-UnB) - Brasilia (DF), Brazil.

M.D. PhD. Residency Preceptor of Dermatology - Dermatology Department, Brasilia University Hospital (HUB-UnB) - Brasilia (DF), Brazil.

M.D. PhD - Associate Professor at University of Brasilia (UnB), Head of the Department of Dermatology, Brasilia University Hospital (HUB-UnB) - Brasilia (DF), Brazil. 


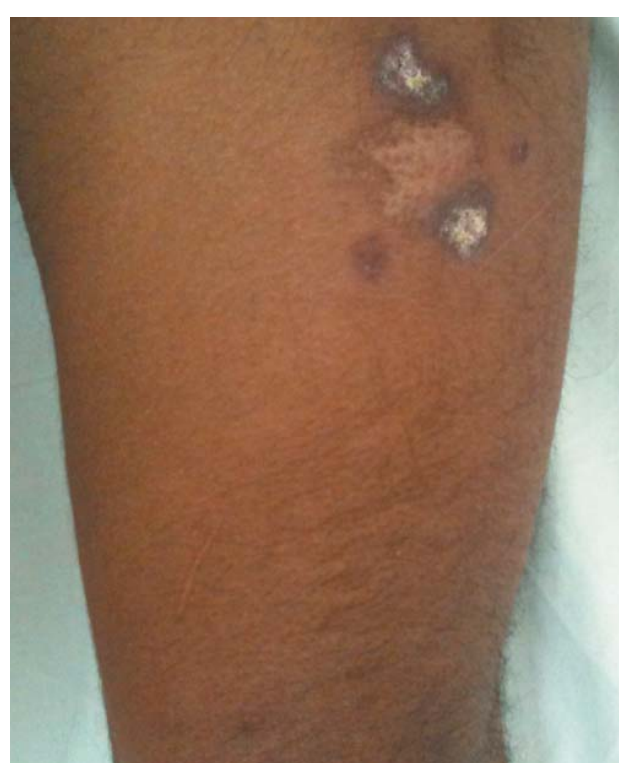

Figure 1:

Lesion with atrophic center permeated with

hyperchromic areas and verrucous nodules on the borders

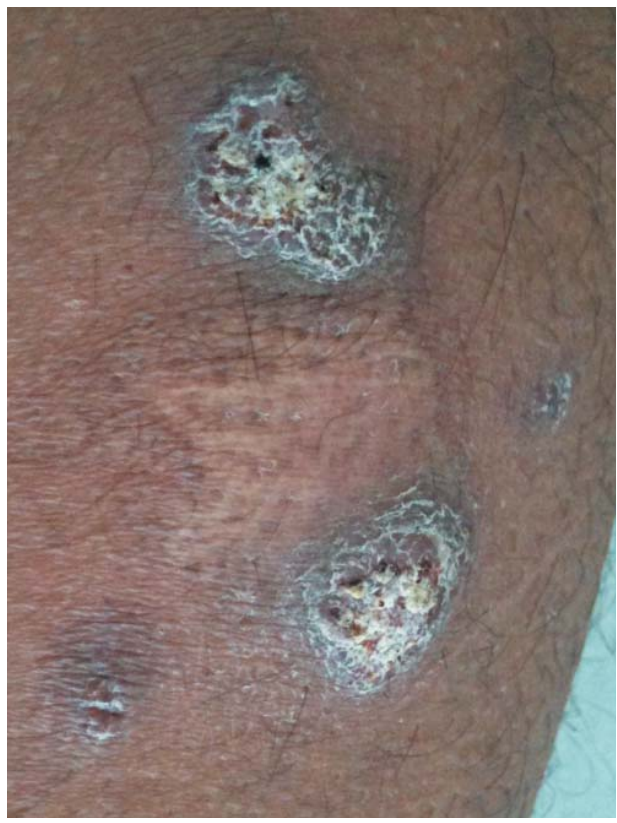

FIGURE 2: Detail of lesion formed by a central atrophic scar and verrucous nodules on the edges

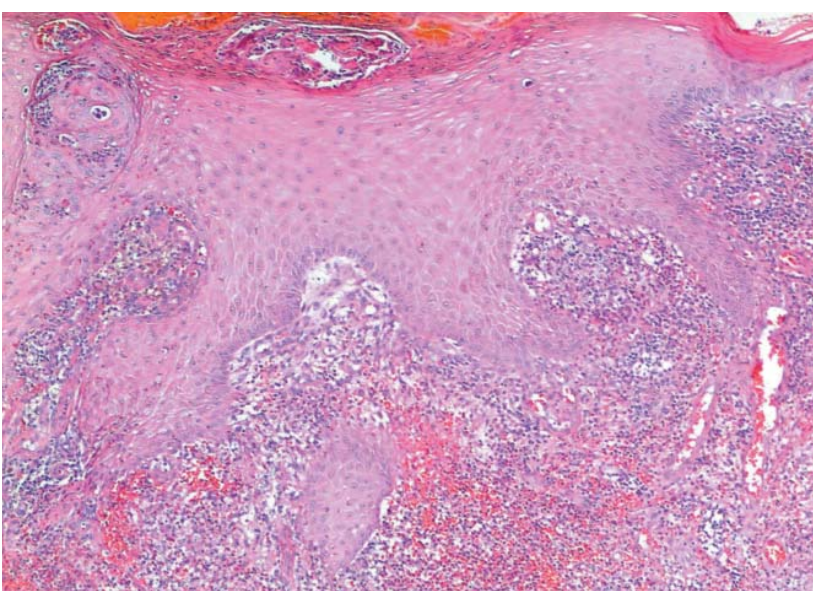

FIGURE 3: Hematoxiciline and eosine stain - 40x: Histopathological examination with marked pseudoepitheliomatous hiperlasia and extensive dermal inflammatory infiltrate

The diagnosis of Recurrent Cutaneous Leishmaniasis (RCL) was confirmed after the positive culture of aspirate specimens using the McNeal, Novy \& Nicolle culture medium. ${ }^{1}$ The species L. (V.) braziliensis $^{2}$ is endemic to the area of Brazil where the patient originated.

We decided to associate $\mathrm{N}$-methylglucamine $(20 \mathrm{mgSbV} / \mathrm{kg} /$ day) with pentoxifylline $(1200 \mathrm{mg} /$ day $)$ for 30 days. ${ }^{3,4}$ The patient achieved a long-term clinical cure, observed over a 3-year follow-up period.

$\mathrm{RCL}$ is rare, usually occurring within two years following the appearance of initial lesions. It is considered by many authors to be the result of inappropriate treatment. ${ }^{5,6}$ Given the challenge of RCL we need to consider long-term follow-up of all cases which apparently have been wrongly treated..$^{3,47}$ Using an association of pentoxifylline in the treatment regime was effective probably due to its immunomodulatory function and its ability to regulate tumor necrosis factor- $\alpha$ levels. ${ }^{8-10} \square$ 


\section{REFERENCES}

1. Calvopina $M$, Uezato $H$, Gomez EA, Korenaga M, Nonaka S, Hashiguchi $Y$. Leishmaniasis recidiva cutis due to Leishmania (Viannia) panamensis in subtropical Ecuador: isoenzymatic characterization. Int J Dermatol. 2006;45:116-20.

2. Brasil. Ministério da Saúde. Secretaria de Vigilância em Saúde. Manual de Vigilância da Leishmaniose Tegumentar Americana. 2. ed. atual. Brasília: Ministério da Saúde; 2007. 180 p.

3. González U, Pinart M, Rengifo-Pardo M, Macaya A, Alvar J, Tweed JA Interventions for American cutaneous and mucocutaneous leishmaniasis. Cochrane Database Syst Rev. 2009:CD004834.

4. Serafinella P, Cannavò SP, Vaccaro M, Guarneri F. Leishmaniasis recidiva cutis. Int J Dermatol. 2000;39:205-6.

5. UI Bari A, Raza N. Lupoid cutaneous leishmaniasis: a report of 16 cases. Indian J Dermatol Venereol Leprol. 2010;76:85.

6. Costa JML, Lago EL, Magalhães AV, Marsden PD. Leishmaniasis recidiva a cutis caused by Leishmania Viannia braziliensis. An Bras Dermatol. 1996;71:329-33.

7. Momeni A-Z, Aminjavaheri M. Treatment of recurrent cutaneous leishmaniasis. Int J Dermatol. 1995;34:129-33.

8. Almeida OL, Santos JB. Advances in the treatment of cutaneous leishmaniasis in the new world in the last ten years: a systematic literature review. An Bras Dermatol. 2011;86:497-506.

9. Machado PR, Lessa H, Lessa M, Guimaraes LH, Bang H, Ho JL, et al. Oral pentoxifylline combined with pentavalent antimony: a randomized trial for mucosal leishmaniasis. Clin Infect Dis. 2007:44:788-93.

10. Gomes CM, Morais 00, Leite AS, Soares KA, Motta J de 0, Sampaio RN. Periungual leishmaniasis. An Bras Dermatol. 2012;87:148-9.

\section{MAILING ADDRESS:}

Ciro Martins Gomes

Hospital Universitário de Brasília SGAN 605,

Av. L2 Norte

70910-900 Brasília - DF

Brazil

E-mail:ciro_m_gomes@yahoo.com.br

How to cite this article: Gomes CM, Damasco FS, Morais OO, Paula CDR, Sampaio RNR. Recurrent cutaneous leishmaniasis. An Bras Dermatol. 2013;88(3):462-4 